\title{
AMPHIBIANS AND REPTILES
}

\section{CLUTCH SIZES IN MANITOBA COMMON SNAPPING TURTLES}

DEAN J. BEREZANSKI, Manitoba Natural Resources, Box 24, 200 Saulteaux Crescent, Winnipeg, MB R3J 3W3

\section{Introduction}

The Common Snapping Turtle (Chelydra serpentina serpentina) is one of two turtle species in Manitoba and ranges into the province as far as approximately $52^{\circ} \mathrm{N}$ Latitude (Figure 1). Seton described it as a "ferocious reptile of great strength and insatiable appetite." 15 By weight, it is Canada's largest reptile: in Manitoba, one unsexed individual found near Sperling had a $533 \mathrm{~mm}$ carapace length and weighed $18 \mathrm{~kg}$. Snapping Turtles live in permanent water bodies and feed on whatever they can find, such as carrion,

Figure 1 - Common Snapping Turtle range in Manitoba and nest locations from this article.

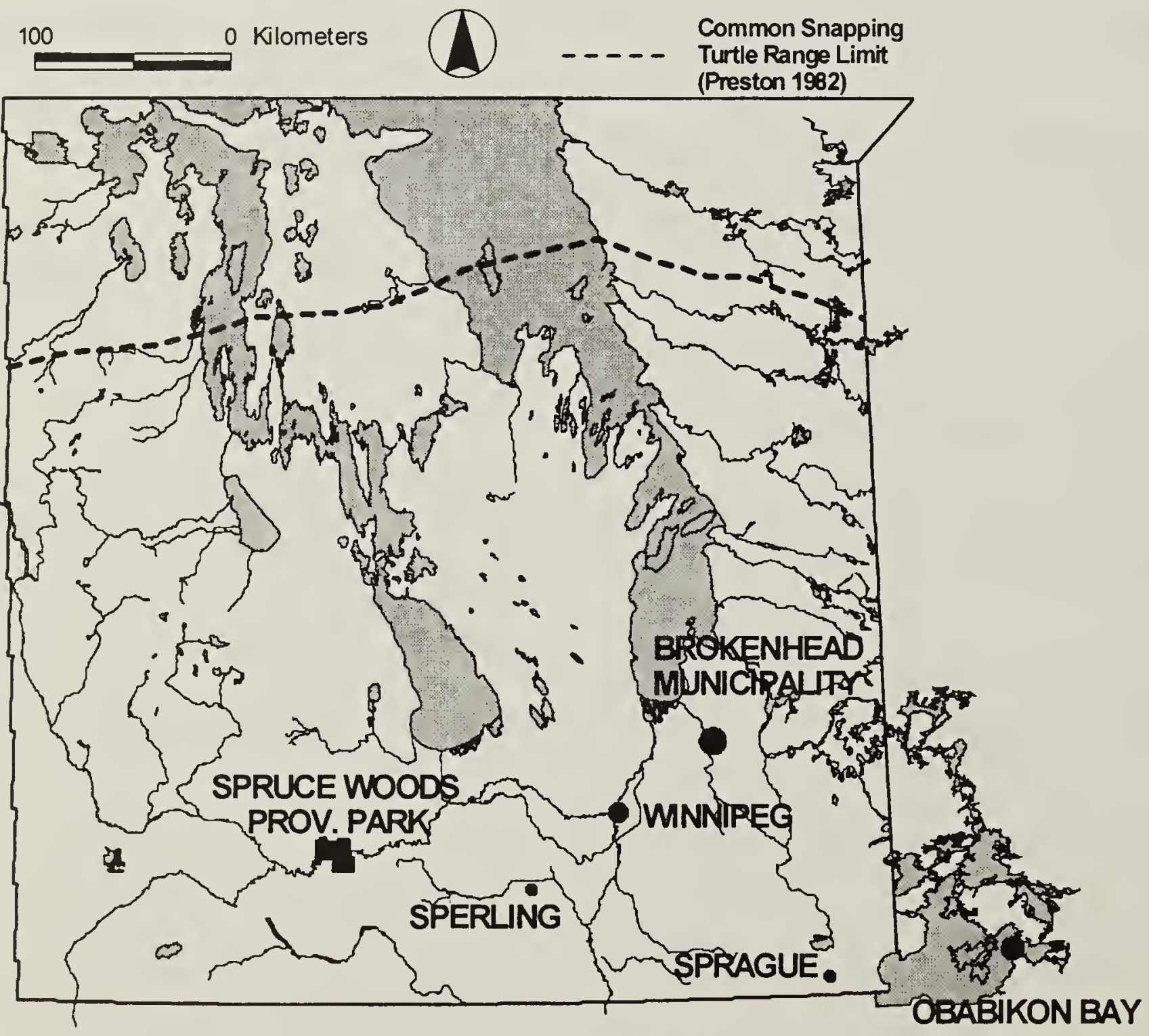


fish, birds, molluscs, and vegetation. They can be aggressively defensive when encountered out of water and their bites can inflict considerable damage. ${ }^{13}$ Studies suggest that maximum age may exceed 50 years. ${ }^{7,8}$

The Common Snapping Turtle lays its eggs usually during June in sandy or gravelly soil near water. ${ }^{13}$ Although given as normally 20-40 eggs, a review of reported clutch sizes across North America gives a range from as few as six eggs in Florida to an unusual 109 eggs from Nebraska. ${ }^{13,8}$ Clutch size for the species is positively related to female body size, altitude,and latitude, but no firm conclusion has been reached relating egg size to female size. ${ }^{8,} 11$ During incubation, temperature of the individual eggs at the critical time of sex determination determines sex of the hatchling. ${ }^{1}$ Incubation for the species can take between 62 and 97 days. ${ }^{13}$
No studies have been done on the fecundity of this species in its Manitoba range. This article reviews reports on clutch sizes from Manitoba, including one from northwestern Ontario, and discusses these sizes relative to the species' life history here and throughout the rest of its North American range.

\section{Methods}

The author collected information on Common Snapping Turtle clutch sizes from personal observations, literature accounts, other individuals, actual counts, and in one case, photographic evidence (Table 1). All the data collected were from chance encounters of nesting turtles, including those from .9 In addition, his record from Obabikon Bay, Lake of the Woods in northwestern Ontario was included because the lake straddles the Ontario-Manitoba border.

\section{Table 1 - Common Snapping Turtle clutch sizes in Manitoba and Region.}

\begin{tabular}{|c|c|c|c|c|}
\hline $\begin{array}{l}\text { Clutch } \\
\text { Size }\end{array}$ & $\begin{array}{l}\text { Location and Approximate } \\
\text { Coordinates }\end{array}$ & Date Observed & Comments & Reference \\
\hline 49 & $\begin{array}{l}\text { Obabikon Bay, Lake of the Woods, } \\
\text { northwestern Ontario; } 49^{\circ} 14^{\prime} \mathrm{N} 94^{\circ} \\
17^{\prime} \mathrm{W}\end{array}$ & July 1944 & & Norris-Elye 1949 \\
\hline 80 & $\begin{array}{l}\text { Assiniboine River at Riverbend Girls? } \\
\text { School (now Balmoral Hall), Winnipeg; } \\
49^{\circ} 53^{\prime} \mathrm{N} 97^{\circ} \text { 09' } \mathrm{W}\end{array}$ & June 17, 1946 & & Norris-Elye 1949 \\
\hline 77 & $\begin{array}{l}\text { Sturgeon Creek at the Assiniboine } \\
\text { River, Winnipeg; } 49^{\circ} 52^{\prime} \mathrm{N} 97^{\circ} 16^{\prime} \mathrm{W}\end{array}$ & June 20,1948 & $26 \mathrm{~mm}$ egg diameter & Norris-Elye 1949 \\
\hline 70 & Sprague River $49^{\circ} 02^{\prime} \mathrm{N} 95^{\circ} 38^{\prime} \mathrm{W}$ & June 18,1982 & $\begin{array}{l}2.6 \mathrm{~km} \text { south of } \\
\text { Sprague; carapace } \\
\text { measured as } 330 \mathrm{~mm} \\
\text { (?13in?) }\end{array}$ & $\begin{array}{l}\text { Preston (unpubl. data, } \\
\text { Man. Museum } \\
\text { Archives) }\end{array}$ \\
\hline 82 & $\begin{array}{l}\text { Kiche Manitou Lake (Pine Fort IV } \\
\text { pathway), Spruce Woods Provincial } \\
\text { Park (SWPP); } 49^{\circ} 39^{\prime} \mathrm{N}, 99^{\circ} 15^{\prime} \mathrm{W}\end{array}$ & June 15, 1989 & $\begin{array}{l}\text { Oxbow of Assiniboine } \\
\text { River; see text }\end{array}$ & Author \\
\hline 59 & $\begin{array}{l}\text { Kiche Manitou Lake (Day Use Area, } \\
\text { outhouse path), SWPP; } 49^{\circ} 39^{\prime} \mathrm{N}, 99^{\circ} \\
15^{\prime} \mathrm{W}\end{array}$ & June 22,1989 & $\begin{array}{l}\text { Oxbow of Assiniboine } \\
\text { River }\end{array}$ & Author \\
\hline 55 & $\begin{array}{l}\text { Kiche Manitou Lake (Playground } \\
\text { sandbox), SWPP; } 49^{\circ} 39^{\prime} \mathrm{N}, 99^{\circ} 15^{\prime} \mathrm{W}\end{array}$ & June 29,1989 & $\begin{array}{l}\text { Oxbow of Assiniboine } \\
\text { River }\end{array}$ & Park staff \\
\hline 49 & $\begin{array}{l}\text { Drainage ditch, Brokenhead } \\
\text { Municipality; } 50^{\circ} 14^{\prime} \mathrm{N} 96^{\circ} 27^{\prime} \mathrm{W}\end{array}$ & June 17,1998 & $\begin{array}{l}0.8 \mathrm{~km} \text { from } \\
\text { Brokenhead River; see } \\
\text { text }\end{array}$ & $\begin{array}{l}\text { R. Shumila (pers. } \\
\text { comm.) }\end{array}$ \\
\hline $56+$ (est.) & $\begin{array}{l}\text { Kiche Manitou Lake; SWPP; } 49^{\circ} 39^{\prime} \mathrm{N} \text {, } \\
99^{\circ} 15^{\prime} \mathrm{W}\end{array}$ & June 24,1979 & $\begin{array}{l}\text { Oxbow of Assiniboine } \\
\text { River; no. based on a } \\
\text { photo of egg pile at } \\
\text { time of relocation; see } \\
\text { text }\end{array}$ & $\begin{array}{l}\text { Preston 1982; } \\
\text { Manitoba Parks Slide } \\
\text { Show ?The Snapping } \\
\text { Turtle? }\end{array}$ \\
\hline $50+$ (est.) & $\begin{array}{l}\text { Kiche Manitou Lake (Visitor Services } \\
\text { Centre), SWPP; } 49^{\circ} 39^{\prime} \mathrm{N}, 99^{\circ} 15^{\prime} \mathrm{W}\end{array}$ & August 1987 & $\begin{array}{l}\text { Oxbow of Assiniboine } \\
\text { River; clutch counted } \\
\text { but no record kept }\end{array}$ & $\begin{array}{l}\text { L.K. Leavesley (pers. } \\
\text { comm.) }\end{array}$ \\
\hline
\end{tabular}


Two estimates are listed in Table 1 because counts of some form were made. These estimates were not included in any calculations. Preston (unpublished data, Man. Museum Archives) has records of clutch size estimates which were not included in this article because no actual counts were made.

\section{Results}

Common Snapping Turtle clutch sizes from Manitoba and northwestern Ontario are given in Table 1. The clutch size for observations where complete counts were made is $65.1 \pm 13.8$ eggs/clutch (mean $\pm s d, n=8$; range $=49-82$ ).

The turtle nests from Spruce Woods Provincial Park (SWPP), except the June 1979 nest, and from the Municipality of Brokenhead, were in locations where egg or potential hatchling survival was deemed hazardous because of human traffic. Eggs were excavated immediately and relocated away from these hazards.
The exact location of the June 1979 nest from SWPP was not known. The clutch was relocated to the trunk of an abandoned car, with subsequent hatching 97 days later of an unrecorded number. ${ }^{13}$ One hatchling from this clutch was albino (Figure 2), of which few have been recorded from Canada. ${ }^{14}$

The June 15, 1989 nest was found by the author the next day, destroyed by raccoons.

The nest in Brokenhead was relocated to a Winnipeg residence garden, with subsequent hatching of 38 eggs at 104 days. These 38 hatchlings were released into the Brokenhead River near the original nest site a few days later. The remaining eggs were then relocated into a terrarium in an apartment, with one egg hatching at 106 days and another at about 114 days. No more eggs had hatched at the time of writing this article (R. Shumila pers. comm.).

Hatching success was not followed up for the other clutches.

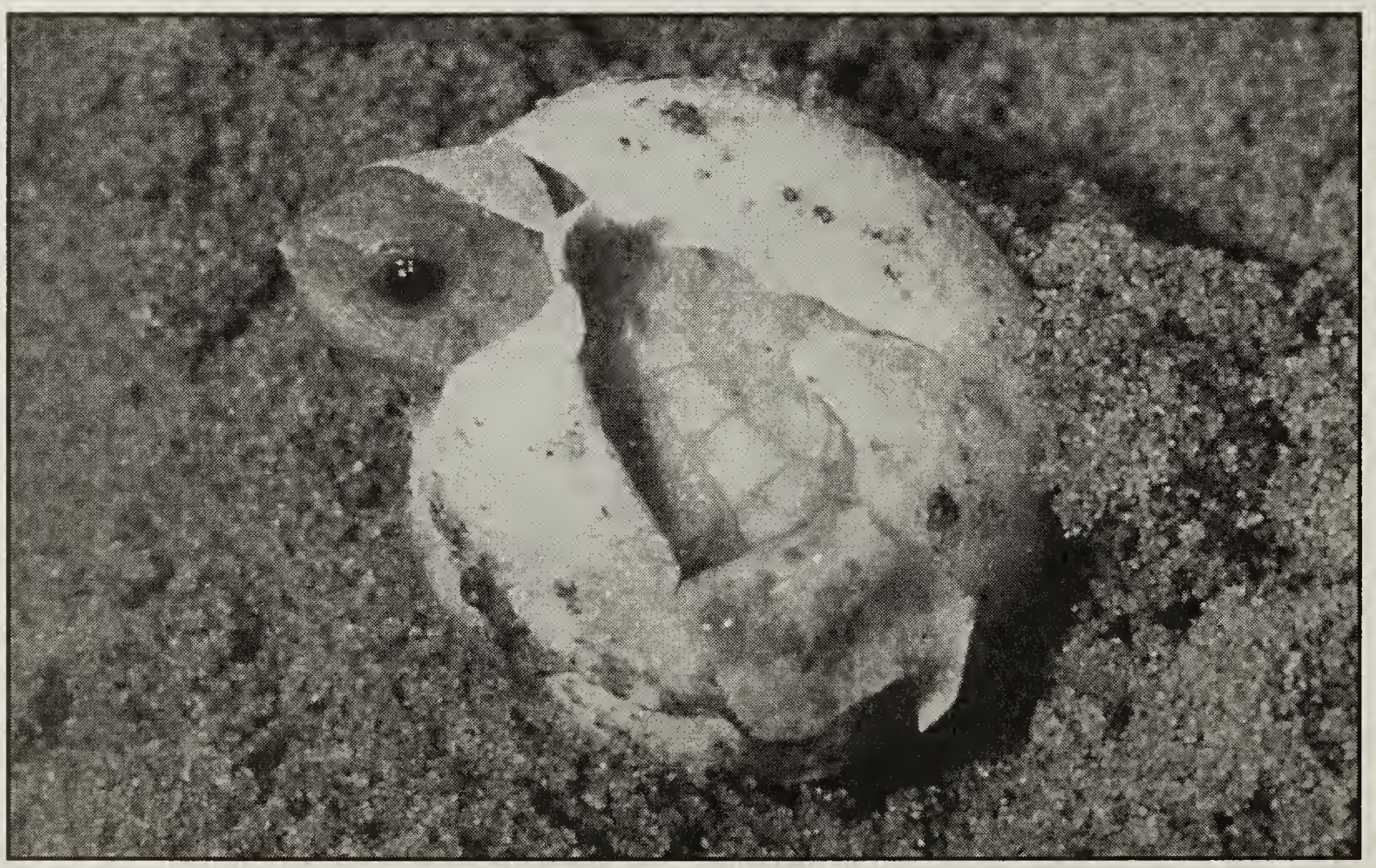

Figure 2 - Albino hatchling Common Snapping Turtle from Spruce Woods Provincial Park, 1979.

T. Ritzer. 
Table 2 - Examples of Common Snapping Turtle clutch sizes

\begin{tabular}{|l|l|}
\hline Mean \pm sd (or se; $n)$ & Locale \\
\hline $65.1 \pm 13.8(n=8)$ & Manitoba (this paper; includes one clutch from NW Ontario) \\
\hline $47.4 \pm 11.3(n=26)$ & Valentine NWR, Nebraska (from raw data in Finkler 1998) \\
\hline $46.8 \pm 11.3(n=77)$ & Crescent Lake NWR, Nebraska ${ }^{10}$ \\
\hline $41.5 \pm 12.86(n=18)$ & Cootes Paradise, Lake Ontario, Ontario ${ }^{3}$ \\
\hline $37 \pm 11(n=255)$ & New York state and Wisconsin ${ }^{19}$ \\
\hline $33.9 \pm 10.03( \pm$ se; $n=46)$ & Algonquin Park, Ontario ${ }^{11}$ \\
\hline $33.0 \pm 8.39(n=18)$ & Algonquin Park, Ontario ${ }^{2}$ \\
\hline $30.9 \pm 10.87(n=16)$ & New York state ${ }^{16}$ \\
\hline $27.9 \pm 0.76( \pm$ se; $n=68)$ & Southeast Michigan ${ }^{5}$ \\
\hline $23.6 \pm 6.6( \pm$ se, $n=4)$ & North Carolina ${ }^{6}$ \\
\hline
\end{tabular}

\section{Discussion}

The mean clutch size for the Common Snapping Turtle in this article is larger than those reported from several other locations (Table 2).

Wildlife populations often exhibit different life strategies when at the extremes of a species' geographic range. Breeding female Common Snapping Turtles at our latitude would be expected to lay larger clutch sizes and have larger body sizes when compared to most U.S. populations. Using carapace length $(C L)$ as an indicator of size, the largest average sizes of breeding females in North America are from populations in South Dakota $(319 \mathrm{~mm})$ and Nebraska $(325 \mathrm{~mm}){ }^{8}$ The only Manitoba female measured was from 1982 and had a $330 \mathrm{~mm} \mathrm{CL}^{13}$

Manitoba Snapping Turtles may also breed at later ages when body sizes are larger and, therefore, larger clutches can be laid. The average age at first nesting was estimated at 17-19 years in Algonquin Provincial Park, Ontario. ${ }^{7}$ In comparison, the youngest nesting females in a Nebraska population were estimated at between 10-12 winters. ${ }^{8}$ The reason for a delay in egg-laying is thought to be that a larger body size improves survival in the harsher northern winter and increases fecundity. ${ }^{7}$

Clutch size may be related to habitat productivity. In a study of two Ontario Snapping Turtle populations, clutch size and clutch mass, when corrected for female body size, were significantly greater in the more productive habitat. ${ }^{3}$ The productivity of the various Manitoba habitats was not measured for comparison with other North American locations.

Snapping Turtle egg biology in Manitoba may differ in other aspects besides clutch size. While Western Painted Turtle eggs overwinter here, such a strategy may not be effective with Snapping Turtle eggs..$^{13}$ Overwintering has been suggested in Manitoba, but its success was shown to be very low in Algonquin Park, Ontario (one successful clutch overwintering out of 129). ${ }^{13,10}$

Partly because of the species' life history traits, the Manitoba Conservation 
Data Centre ranks the Common Snapping Turtle as "Uncommon" and indicates that it may be subject to largescale disturbances. ${ }^{6}$ One such disturbance was reported in spring 1991 in Badger Creek, near Cartwright in southwestern Manitoba ${ }^{5}$ when over 40 Snapping and numerous Western Painted turtles were found dead or dying. Effluent was released into the creek earlier in the season from a hog farm waste lagoon upstream (C. Dixon, retired biologist, pers. comm.). In Algonquin Park, Ontario, the natural mortality of a Snapping Turtle population increased 20-fold over two years. Thought to be caused largely by otter predation, the estimated turtle population dropped by $65 \%$. Subsequent studies on the potential long-term impacts from this sudden increase in natural mortality ${ }^{2}$ emphasize the need for more research on the turtle's life history in Manitoba.

\section{Acknowledgements}

My thanks to: $W$. Preston and the Manitoba Museum for access to their records; Spruce Woods Provincial Park staff for information on nesting turtles; $C$. Scott, L.K. Leavesley, J. Duncan, and W. Koonz for reviews of earlier drafts; J. B. Iverson, W.G. Degenhardt, and M. Finkler for their help in locating references.

\section{Literature Cited}

1.BOBYN, M.L. AND R.J. BROOKS. 1994. Incubation conditions as potential factors limiting the northern distribution of snapping turtles, Chelydra serpentina. Can. J. Zool. 72:28-37.

2.BROOKS, R.J., G.P. BROWN., AND D.A. GALBRAITH. 1991. Effects of a sudden increase in natural mortality of adults on a population of the common snapping turtle (Chelydra serpentina). Can. J. Zool. 69:1314-1320.
3.BROWN, G.P. C.A. BISHOP, AND R.J. BROOKS. 1994. Growth rate, reproductive output, and temperature selection of snapping turtles in habitats of different productivities. J. Herpetol. 28(4):405-410.

4.CONGDON, J.D. AND J.W. GIBBONS. 1985. Egg components and reproductive characteristics of turtles: relationships to body size. Herpetologica 41:194-205.

5.DIXON, C. 1991. Wild things. Boissevain Recorder, May 29, 1991. Pg. 20.

6. DUNCAN, J. 1996. Conservation status ranks of the reptiles of Manitoba. Man. Conservation Data Centre MS Report 96-03, Winnipeg. 6pp.

7.GALBRAITH, D.A., R.J. BROOKS, AND M.E. OBBARD. 1989. The influence of growth rate on age and body size at maturity in female snapping turtles (Chelydra serpentina). Copeia 1984(4):896-904.

8.IVERSON J.B., H. HIGGINS, A. SIRULNIK, AND C. GRIFFITHS. 1997. Local and geographic variation in the reproductive biology of the snapping turtle (Chelydra serpentina). Herpetologica 53(1):96-117.

9.NORRIS-ELYE, L.T.S. 1949. The common snapping turtle (Chelydra serpentina) in Manitoba. Can. Field-Nat. 63:145-147.

10. OBBARD, M.E. AND R.J. BROOKS. 1981. Fate of overwintered clutches of the Common Snapping Turtle (Chelydra serpentina) in Algonquin Park, Ontario. Can. Field-Nat. 95:350-352. 
11. PACKARD, G. C., M.J. PACKARD and K. Miller. 1990. Chelydra serpentina (Common Snapping Turtle). Fecundity, Herpet. Rev.21:92

12. PETOKAS, P.J. AND M.M. ALEXANDER. 1980. The nesting of Chelydra serpentina in northern New York. J. Herpetol. 14:239-244.

13. PRESTON, W.B. 1982. The amphibians and reptiles of Manitoba. Man. Museum of Man and Nature, Winnipeg. 128 pp.
14. SAUMURE, R.A. AND D. RODRIGUE. 1998. An albino snapping turtle, Chelydra serpentina, from Quebec . Can. Field-Nat. 112:344.

15. SETON, E.T. 1918. A list of the turtles, snakes, and batrachians of Manitoba. Ottawa Field-Nat. 32:79-83.

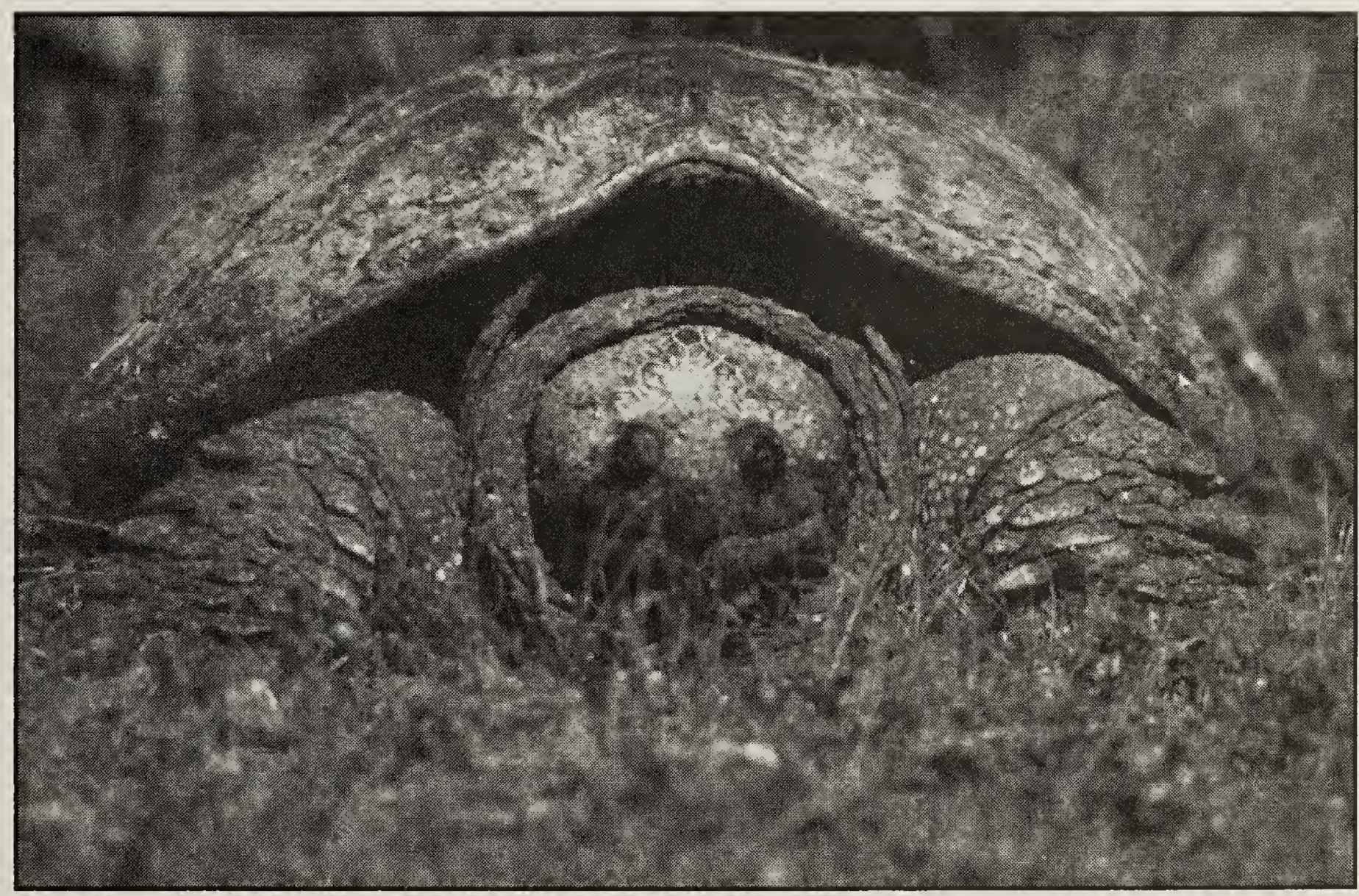

Adult female Common Snapping Turtle, Spruce Woods Provincial Park June 15, 1989

D.J. Berezanski 